\title{
Fertility and hatchability of Japanese quail eggs under semi arid conditions in Nigeria
}

${ }^{1}$ Raji, A. O., ${ }^{2}$ Mbap, S.T and ${ }^{1}$ Kwari, I. D.

${ }^{1}$ Department of Animal Science, University of Maiduguri, Maiduguri, Nigeria

${ }^{2}$ Animal Production Programme, Abubakar Tafawa Balewa University, Bauchi, Nigeria

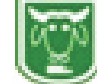

\begin{abstract}
Some factors affecting the fertility and hatchability of Japanese quail eggs were studied at the Poultry Unit of the University of Maiduguri Livestock Teaching and Research Farm. A total of 1850 eggs were used for the study and data collected were subjected to Analysis of Variance. The mean values of fertility, hatchability of total and fertile eggs set, early, mid and late embryo mortalities were $74.33,51.35,69.09,10.25,7.57$ and $12.30 \%$ respectively. Fertility was highest (84.92\%) in the dry cold, least (35.58\%) in the dry hot, with wet season $(80.75 \%)$ being intermediate. Similarly, hatchability of total and fertile eggs set were 67.18 and $79.11 \%$ in the dry cold, 14.11 and $39.66 \%$ in the dry hot and 46.86 and $58.03 \%$ in the wet season. Younger quails ( $\leq 10$ and 11-22 weeks) had higher fertility and hatchability than older ones (23-34 and 35-52 weeks). Early embryo mortality also increased with age. Fertility and hatchability of eggs from caged birds was 89.54 and $62.34 \%$ as compared to 54.93 and $37.35 \%$ from deep litter reared birds and hatchability of fertile eggs was 69.63 and $67.96 \%$ respectively. Fertility and hatchability was highest (92.15 and $71.48 \%$ ) for birds of ratio 1:3 and least for 1:5 (19.60 and 10\%). Breeders that weighed 181-200 g had the highest hatchability (79.22\%) and $\leq 140 \mathrm{~g}$ the least (60.83\%). In contrast, breeder's with weights $\leq$ $140 \mathrm{~g}$ had the highest late embryo mortality (20\%) and 141-160 $\mathrm{g}$ the least (9.67\%). Light brown quails had lower hatchability of total and fertile eggs (23.71\% and 35.71\%) as compared to wild type or normal colored ones (52.04\% and 69.84\%). Light brown, however, had higher $(P<0.05)$ early and late embryo mortalities $(21.43 \%$ and $35.71 \%)$ than wild type $(10.0 \%$ and $11.77 \%)$. It can be concluded from this study that for optimum fertility and hatchability, Japanese quail should be reared in cages at a mating ratio of 1:3 male to female.
\end{abstract}

Keywords: colour, flock age, hatchability, Japanese quail, season

\section{Introduction}

Quail rearing for egg production has become an economically viable activity especially in Northern Nigeria and it is increasingly being developed because of increasing interest in the eggs for food and medicine. The objective of any commercial hatchery is to obtain the maximum number of quality chicks out of the eggs set for hatching (Islam et al., 2002). Fertility and hatchability are very important determinants for producing more chicks from a given number of breeding stocks within a stipulated period and are interrelated heritable traits that vary among breeds, varieties and individuals within breeds and varieties (Coony, 1943). They are affected by a number of factors including breeder weight, mating ratio and breeder age (Ipek et al., 2004) and period and condition of egg storage and egg weight (Seker et al., 2004). The latter researchers also reported fertility and hatchability of 62.07 and $57.93 \%$ respectively for quails. 
Inosco et al. (1971) observed gradual increase in fertility and hatchability up to 12 - 14 weeks age and a decline to 19 weeks with further increase thereafter. Tona et al. (2001) also observed that the decline in hatchability with age was due to embryonic mortality in broiler breeders. Narahari et al. (1988) reported fertility rates of $87.7,90.0$ and $93.6 \%$ for Japanese quails grouped into light (171-200 g), medium (201-230 g) and heavy ( $>230 \mathrm{~g})$ weights, respectively. The corresponding hatchability values were 76.5, 82.9 and $85.2 \%$. Ipek et al. (2004) observed that the best fertility rates were obtained in groups that had 1:2 and 1:3 male to female ratios but declined for 1:1 and 1:5 groups. In contrast, Narahari et al. (1988) reported that sex ratios of 1:2 and 1:5 had comparable fertility and hatchability values. There is a dearth of information on the fertility and hatchability of Japanese quail eggs in Nigeria especially the semiarid areas. Moreover, there is variation in the values of fertility and hatchability of Japanese quail eggs reported by different authors. They also differed on the effects of some factors. The aim of this study was to determine the effects of some factors on fertility and hatchability of Japanese quail eggs.

\section{Materials and methods}

The study was carried out at the Poultry Unit of the University of Maiduguri Livestock Teaching and Research Farm, Maiduguri, Borno State, Nigeria. Maiduguri, the Borno State capital is situated on latitude $11^{\circ} 5^{\prime} \mathrm{N}$, longitude $13^{\circ} 09^{\prime}$ E (Encarta, 2007) and at an altitude of 354 $\mathrm{m}$ above sea level. The area falls within the Sahelian region of West Africa, which is noted for great climatic and seasonal variations. It has very short period $(3-4$ months) of rainfall of $645.9 \mathrm{~mm} / \mathrm{annum}$ with a long dry season of about $8-9$ months. The ambient temperature could be as low as $20^{\circ} \mathrm{C}$ during the dry cold season and as high as $44^{\circ} \mathrm{C}$ in the dry hot season. Relative humidity is $45 \%$ in August which usually lowers to about 5\% in December and January. Day length varies from 11 to 12 hours (Alaku, 1982). A total of 1850 eggs were collected from a random bred Japanese quail flock housed in cages ( $30 \mathrm{x}$ $30 \times 45 \mathrm{~cm}$ ) and deep litter pens. A breeder's diet containing $18 \%$ crude protein and 2800 $\mathrm{kcal} / \mathrm{kg}$ of Metabolisable Energy (NRC, 1994) was fed ad libitum. Clean drinking water was also provided ad libitum.

Eggs for incubation were collected twice daily (morning and evening), weighed on a sensitive balance, marked appropriately with a permanent marker, placed in quail crates with broad ends up and incubated artificially at the appropriate time with a forced air incubator (1510 Sportsman cabinet-type incubator, GQF Mfg. Co. USA.). The eggs were turned automatically until the $15^{\text {th }}$ day. Incubation temperature and humidity was $37.5{ }^{\circ} \mathrm{C}$ and $60 \%$ respectively. After 18 days of incubation, hatched chicks and unhatched eggs were removed. At the end of hatching, apparently fertile or infertile eggs were determined by breaking them open. Infertile eggs had no blood islet while fertile ones had blood islet or embryo.

Fertility was calculated as:

Number of fertile eggs $\quad x 100$ Total number of eggs set

Hatchability was calculated as:

$=$ Number of chicks hatchedx 100

Number of fertile eggs set 
Hatchability of total eggs set was calculated as:

Number of chicks hatched

Number of eggs set

Eggs that did not hatch were opened, and contents macroscopically examined to determine early, mid and late embryonic mortality as described by Reynnells et al. (1977) and Mani et al. (2008). Early embryonic mortality occurred when blood islet or very small embryo with very large yolk sac was observed: Mid-term embryonic mortality; when medium sized embryo and yolk sac were observed: late embryonic mortality; when a fully formed embryo with completely, or almost completely absorbed yolk sac was observed.

The data generated was subjected to Analysis of Variance using the General Linear Model (GLM) procedure of SPSS 13.0. Significant means where applicable were separated by Duncan's Multiple Range Test. The model for the analysis was

$\mathrm{Y}_{\mathrm{ijklmn}}=\mathrm{A}_{\mathrm{i}}+\mathrm{B}_{\mathrm{j}}+\mathrm{C}_{\mathrm{k}}+\mathrm{D}_{1}+\mathrm{F}_{\mathrm{m}}+\mathrm{G}_{\mathrm{n}}+\mathrm{e}_{\mathrm{ijklmn}}$ Where $\mathrm{Y}_{\mathrm{ijklm}}=$ observation on individual measurements based on the $i j k l m$ classification

$A_{i}=$ fixed effect of season

$B_{j}=$ fixed effect of flock age

$\mathrm{C}_{\mathrm{k}}=$ fixed effect of production system

$\mathrm{D}_{1}=$ fixed effect of mating ratio

$\mathrm{F}_{\mathrm{m}}=$ fixed effect of color

$\mathrm{G}_{\mathrm{n}}=$ fixed effect of breeder weight

$\mathrm{e}_{\mathrm{ijk} \mathrm{lmn}}=$ random error

\section{Results and discussion}

Fertility and hatchability values as affected by season and flock age are presented in Table 1. The mean values of fertility, hatchability of total and fertile eggs set, early, mid and late embryo mortalities were $74.33,51.35,69.09,10.25,7.57$ and $12.30 \%$ respectively.

Season

Season had significant effect on Fertility and hatchability of total and fertile eggs set

Table 1. Effect of season and flock age on fertility and hatchability traits of Japanese quail eggs

\begin{tabular}{lllllll}
\hline & \multicolumn{2}{l}{ Total eggs set } & \multicolumn{3}{l}{ Fertile eggs } & \multicolumn{2}{l}{ Embryo mortalities (\%) } \\
& Fertile $(\%)$ & Hatch $(\%)$ & Hatch $(\%)$ & Early & Mid & Late \\
\hline Overall & 74.33 & 51.35 & 69.09 & 10.25 & 7.57 & 12.30 \\
& & & & & & \\
Season & $* * *$ & $* * *$ & $* * *$ & $* *$ & $* *$ & ns \\
Dry cold & $84.92^{\mathrm{a}}$ & $67.18^{\mathrm{a}}$ & $79.11^{\mathrm{a}}$ & $6.53^{\mathrm{b}}$ & $2.35^{\mathrm{b}}$ & $10.70^{\mathrm{a}}$ \\
Dry hot & $35.58^{\mathrm{c}}$ & $14.11^{\mathrm{c}}$ & $39.66^{\mathrm{c}}$ & $12.07^{\mathrm{a}}$ & $39.66^{\mathrm{a}}$ & $8.62^{\mathrm{a}}$ \\
Rain & $80.75^{\mathrm{b}}$ & $46.86^{\mathrm{b}}$ & $58.03^{\mathrm{b}}$ & $17.10^{\mathrm{a}}$ & $8.29^{\mathrm{b}}$ & $16.58^{\mathrm{a}}$ \\
& & & & & & \\
Flock age & & & & & & \\
(weeks) & $* * *$ & $* * *$ & $*$ & $*$ & $*$ & $\mathrm{~ns}$ \\
$=10$ & $74.29^{\mathrm{b}}$ & $61.43^{\mathrm{a}}$ & $82.69^{\mathrm{a}}$ & $1.92^{\mathrm{b}}$ & $3.85^{\mathrm{b}}$ & $7.69^{\mathrm{a}}$ \\
$11-22$ & $85.27^{\mathrm{a}}$ & $60.37^{\mathrm{a}}$ & $70.80^{\mathrm{a}}$ & $9.73^{\mathrm{ab}}$ & $5.60^{\mathrm{b}}$ & $13.87^{\mathrm{a}}$ \\
$23-34$ & $38.74^{\mathrm{c}}$ & $26.18^{\mathrm{c}}$ & $67.57^{\mathrm{b}}$ & $14.86^{\mathrm{a}}$ & $0.00^{\mathrm{b}}$ & $13.51^{\mathrm{a}}$ \\
$35-52$ & $88.18^{\mathrm{a}}$ & $49.09^{\mathrm{b}}$ & $55.67^{\mathrm{c}}$ & $13.40^{\mathrm{a}}$ & $23.71^{\mathrm{a}}$ & $7.22^{\mathrm{a}}$ \\
SEM & 1.50 & 1.71 & 1.84 & 1.21 & 1.05 & 1.31 \\
\hline
\end{tabular}

Means in a column within a subset with different superscripts $\mathrm{a}, \mathrm{b}$ are significantly different ns $=$ not significant, $*=\mathrm{P}<0.05, * *=\mathrm{P}<0.01, * * *=\mathrm{P}<0.001$ 
$(\mathrm{P}<0.001)$, early and mid embryonic mortality $(\mathrm{P}<0.01)$ while egg weight and late embryonic mortality were not. Fertility was highest $(84.92 \%)$ in the dry cold, least $(35.58 \%)$ in the dry hot with wet season $(80.75 \%)$ being intermediate. Similarly, hatchability of total and fertile eggs set were 67.18 and $79.11 \%$ in the dry cold, 14.11 and $39.66 \%$ in the dry hot and 46.86 and $58.03 \%$ in the wet season. Early embryo mortality was highest $(17.10 \%)$ in the wet season and least $(6.55 \%)$ in the dry cold while mid embryonic mortality was highest (39.64) in the dry hot and least 2.35 in the dry cold season. Uddin et al. (1994) however, reported non significant effect of season on fertility, hatchability and embryo mortality of quail eggs.

\section{Flockage}

Flock age had significant effect on fertility and hatchability of total eggs $(\mathrm{P}<0.001)$, hatchability of fertile eggs, early and mid embryo mortality $(\mathrm{P}<0.05)$ but non significant effect on late embryo mortality and egg weight. The fertility and hatchability of total eggs, respectively, for the flock age groups $\leq 10,11-22,23-34$ and $35-52$ weeks were 74.29 and 61.43 , 85.27 and 60.37 ; 38.74 and 26.18; and, 88.18 and $49.09 \%$. The corresponding hatchability of fertile eggs were 82.69, $70.80,67.57$ and $55.67 \%$. Thus, fertility and hatchability were higher at younger $(\leq$ 10 and 11-22) than older ages (23-34 and 35-52 weeks). Early embryo mortality also increased with age. The $\leq 10$ weeks age group had the least (1.92\%) and 35-52 weeks had the highest (13.4\%). Similarly, mid embryo mortality was $3.85 \%$ for $\leq 10$ and $23.71 \%$ for $35-52$ weeks.

The significant effect of flock age on fertility and hatchability parameters of Japanese quail eggs observed in this study has also been reported by Narahari et al.
(1988) and Seker et al. (2004). Inosco et al. (1971) observed gradual increases in fertility and hatchability of incubated Japanese quail eggs up to 12-14 weeks and a decline thereafter to 19 weeks of age. This was followed immediately by another increase. It was observed in this study that hatchability of fertile eggs decreased with increasing age of flock. This is consistent with reports in literature (Lowe and Garwood, 1977; Erensayin, 2002; Sahan and Ipek, 2000; Tona et al., 2001 and Reddish et al., 2003). Narahari et al. (1988) also reported higher rates of fertility and hatchability of Japanese quail eggs from parents 10 - 19 weeks of age with peak at 12 - 14 weeks. Similarly, Seker et al. (2004) reported higher fertility $(78.92 \%$ vs $62.07 \%)$ and hatchability $(64.34 \%$ vs $57.93 \%$ ) for younger than older quails respectively. Rizk et al. (2006) however did not observe any significant effect of breeder age on fertility and hatchability in a study involving quails that were $16-24$ and 24 - 32 weeks. They reported fertility of $86.89 \%$ and $87.44 \%$ and hatchability of $75.44 \%$ and $80.78 \%$. Dere et al. (2009) also did not observe any significant effect of parental age on the fertility and hatchability of Japanese quail eggs. In their study, they reported fertility and hatchability values for two age groups (3 and 6 months) as $82.01 \%$ vs $81.75 \%$ and $71.11 \%$ vs $72.89 \%$. Fertility and hatchability have also been found to vary with hen age in broilers (Fasenko et al., 1992) and Turkey (Sexton, 1977). The decline in hatchability of fertile eggs with increasing age of the breeders may be caused by embryonic mortality. The age of the breeder is thus an important parameter to take into account when collecting eggs for hatching. Contrary to the results of this study, Sari et al. (2010) reported significant effect of flock age on late embryo mortality. 


\section{Production system}

The effect of production system on fertility and hatchability of Japanese quail eggs is presented on Table 2. Production system had significant $(\mathrm{P}<0.001)$ effect on fertility and hatchability of total eggs set but did not significantly affect hatchability of fertile eggs and embryo mortalities. Fertility and hatchability of eggs from caged birds was 89.54 and $62.34 \%$ as compared to 54.93 and $37.35 \%$ from deep litter reared birds and hatchability of fertile eggs was 69.63 and $67.96 \%$ respectively.

This agrees with the report of Roshdy et al. (2010) who observed non significant effect of production system on hatchability and embryo mortality of fertile Japanese quail eggs. Similarly, Narahari et al. (1988) reported that hatching performances of quail eggs from cage and deep litter reared breeders were comparable. The significant effect of production system on fertility observed in this study corroborates the study of Sayed (2006) which reported fertility of 89.3 and $84.85 \%$ for birds housed in batteries and on floor, respectively. In contrast, Roshdy et al (2010) did not observe significant production system effect on fertility.

\section{Mating ratio}

The effect of mating ratio on fertility and hatchability of Japanese quail eggs is presented in Table 2. Mating ratio had significant effect on fertility and hatchability of total eggs $\operatorname{set}(\mathrm{P}<0.001)$, and hatchability of fertile eggs and early embryo mortality $(\mathrm{P}<0.05)$. On the other hand, the effect on mid and late embryo mortality and egg weight was not significant. Fertility was highest $(92.15 \%)$ for birds of ratio 1:3 and least for 1:5 (19.60\%). Mating ratios; $1: 1(82.50 \%)$ and $1: 2(79.17 \%)$ did not differ significantly from mating ratio 1:3 (92.15\%). However, they all differed significantly from ratios $1: 4(60 \%)$ and $1: 5(19.60 \%)$ which also differed significantly. The ratio of 1:3 had the highest, 65.87 and $71.48 \%$, hatchability of total and fertile eggs set respectively while the ratio of 1:5 had the lowest ( 6 and $10 \%$ ). In contrast, 1:5 had the highest early embryo mortality value (90\%) while 1:3 had the least $(7.59 \%)$.

Mating ratio is an important determinant of good fertility (Jadhav and Siddiqui, 2007). The significant effect of mating ratio on fertility and hatchability of Japanese quail eggs observed in this study had also been previously reported (Woodard et al., 1973; Narahari et al., 1988; Altan and Oguz, 1993; Ipek et al., 2004a and Jadhav and Siddiqui, 2007). In this present study, fertility rates for ratios 1:1-1:3 were higher than those of 1:4 and 1:5. This agrees with Gebreil (2002) who reported that flock fertility increased significantly with increasing females to males up to the mating ratio $1: 3$ and declined thereafter. Peak fertility in this study was at ratio 1:3 $(92.15 \%)$ which agrees with the findings of Narahari et al. (1988) that peak fertility was $1: 3(95.4 \%)$ and declined significantly to $(86.4 \%)$ at $1: 6$. They also reported that mating ratios of $1: 1,1: 2,1: 3,1: 4,1: 5$ and 1:6 male to females resulted in fertility percentages of $87.2,95.0,95.4,93.4,80.0$ and $86.4 \%$, respectively. Ipek et al. (2004a) reported significant $(\mathrm{P}<0.05)$ effect of mating ratio on hatchability which corroborates the findings of this study. They obtained hatchability values of $78.1 \%$, $84.6 \%, 85.2 \%, 81.5 \%$ and $78.22 \%$ at mating ratios of 1:1, 1:2, 1:3, 1:4 and 1:5 respectively. Similar findings were reported by Mandour and Sharaf (1993) and Gebreil (2002). Gebreil (2002) in his study observed that hatchability percentage of fertile eggs were 82.16, 87.30, 87.25, 87.43, 
Fertility and hatchability of Japanese quail eggs under semi-arid conditions

Table 2. Effects of production system, mating ratio, breeders weight and color on fertility and hatchability of Japanese quail eggs.

\begin{tabular}{|c|c|c|c|c|c|c|c|}
\hline & \multicolumn{2}{|c|}{ Total eggs set } & \multirow{2}{*}{$\begin{array}{l}\text { Fertile eggs } \\
\text { Hatch }(\%)\end{array}$} & \multicolumn{3}{|c|}{ Embryo mortalities (\%) } & \multirow{2}{*}{$\begin{array}{l}\text { Egg } \\
\text { weight } \\
(\mathrm{g})\end{array}$} \\
\hline & Fertile $(\%)$ & Hatch $(\%)$ & & Early & Mid & Late & \\
\hline Overall & 74.33 & 51.35 & 69.09 & 10.25 & 7.57 & 12.30 & 9.33 \\
\hline Production & & & & & & & \\
\hline system & $* * *$ & $* * *$ & ns & ns & ns & ns & ns \\
\hline Cage & $89.54^{\mathrm{a}}$ & $62.34^{\mathrm{a}}$ & $69.63^{\mathrm{a}}$ & $9.58^{\mathrm{a}}$ & $9.35^{\mathrm{a}}$ & $10.98^{\mathrm{a}}$ & $9.49^{\mathrm{a}}$ \\
\hline Litter & $54.93^{\mathrm{a}}$ & $37.33^{\mathrm{a}}$ & $67.96^{\mathrm{a}}$ & $11.65^{\mathrm{a}}$ & $3.88^{\mathrm{a}}$ & $15.05^{\mathrm{a}}$ & $9.00^{\mathrm{b}}$ \\
\hline Mating ratio & $* * *$ & $* * *$ & $*$ & $*$ & ns & ns & ns \\
\hline $1: 1$ & $82.50^{\mathrm{a}}$ & $53.75^{\mathrm{a}}$ & $65.15^{\mathrm{a}}$ & $18.18^{\mathrm{bc}}$ & $3.03^{\mathrm{a}}$ & $13.64^{\mathrm{a}}$ & $9.30^{\mathrm{a}}$ \\
\hline $1: 2$ & $79.17^{\mathrm{a}}$ & $20.83^{\mathrm{c}}$ & $26.32^{\mathrm{b}}$ & $42.11^{\mathrm{b}}$ & $21.05^{\mathrm{a}}$ & $10.53^{\mathrm{a}}$ & $9.47^{\mathrm{a}}$ \\
\hline $1: 3$ & $92.15^{\mathrm{a}}$ & $65.87^{\mathrm{a}}$ & $71.48^{\mathrm{a}}$ & $7.59^{\mathrm{c}}$ & $7.59^{\mathrm{a}}$ & $12.41^{\mathrm{a}}$ & $9.33^{\mathrm{a}}$ \\
\hline $1: 4$ & $60.00^{\mathrm{b}}$ & $40.00^{\mathrm{b}}$ & $66.67^{\mathrm{a}}$ & $16.67^{\mathrm{bc}}$ & $16.67^{\mathrm{a}}$ & $0.00^{\mathrm{a}}$ & $9.50^{\mathrm{a}}$ \\
\hline $1: 5$ & $19.60^{\mathrm{c}}$ & $6.00^{\mathrm{d}}$ & $10.00^{\mathrm{b}}$ & $90.00^{\mathrm{a}}$ & $0.00^{\mathrm{a}}$ & $0.00^{\mathrm{a}}$ & $8.67^{\mathrm{a}}$ \\
\hline Breeder's & & & & & & & \\
\hline weight (g) & ns & ns & $*$ & $*$ & ns & $*$ & $* * *$ \\
\hline$=140$ & $79.47^{\mathrm{a}}$ & $48.34^{\mathrm{a}}$ & $60.83^{\mathrm{b}}$ & $7.50^{\mathrm{ab}}$ & $11.67^{\mathrm{a}}$ & $20.00^{\mathrm{a}}$ & $9.23^{\mathrm{c}}$ \\
\hline $141-160$ & $73.70^{\mathrm{a}}$ & $50.87^{\mathrm{a}}$ & $69.02^{\mathrm{ab}}$ & $13.33^{\mathrm{a}}$ & $6.67^{\mathrm{a}}$ & $9.80^{\mathrm{b}}$ & $9.10^{\mathrm{c}}$ \\
\hline $161-180$ & $69.76^{\mathrm{a}}$ & $49.76^{\mathrm{a}}$ & $71.33^{\mathrm{ab}}$ & $11.19^{\mathrm{a}}$ & $5.59^{\mathrm{a}}$ & $10.49^{\mathrm{b}}$ & $9.31^{\mathrm{c}}$ \\
\hline $181-200$ & $77.78^{\mathrm{a}}$ & $61.62^{\mathrm{a}}$ & $79.22^{\mathrm{a}}$ & $2.60^{\mathrm{b}}$ & $6.49^{\mathrm{a}}$ & $11.69^{\mathrm{b}}$ & $9.64^{b}$ \\
\hline$>200$ & $75.00^{\mathrm{a}}$ & $50.00^{\mathrm{a}}$ & $66.67^{\mathrm{ab}}$ & $10.26^{\mathrm{a}}$ & $10.26^{\mathrm{a}}$ & $12.82^{\mathrm{b}}$ & $10.62^{a}$ \\
\hline Color & $* * *$ & $* * *$ & $* *$ & $*$ & $\mathrm{~ns}$ & $*$ & ns \\
\hline Wild type & $74.52^{\mathrm{a}}$ & $52.04^{\mathrm{a}}$ & $69.84^{\mathrm{a}}$ & $10.00^{\mathrm{b}}$ & $7.58^{\mathrm{a}}$ & $11.77^{\mathrm{b}}$ & $9.33^{\mathrm{a}}$ \\
\hline Light brown & $66.67^{\mathrm{b}}$ & $23.81^{\mathrm{b}}$ & $35.71^{\mathrm{b}}$ & $21.43^{\mathrm{a}}$ & $7.14^{\mathrm{a}}$ & $35.71^{\mathrm{a}}$ & $9.21^{\mathrm{a}}$ \\
\hline SEM & 1.50 & 1.71 & 1.84 & 1.21 & 1.05 & 1.31 & 0.03 \\
\hline
\end{tabular}

ns $=$ not significant, $*=\mathrm{P}<0.05, * *=\mathrm{P}<0.01, * * *=\mathrm{P}<0.001$

84.61 and $82.53 \%$ at mating ratios of $1: 1$, $1: 2,1: 3,1: 4,1: 5$ and 1:6 respectively. In contrast, Narahari et al. (1988) reported that mating ratios $1: 1,1: 2,1: 3,1: 4,1: 5$ and $1: 6$ gave comparable hatchability of 76.6, 75.7, $74.6,74.3,72.6$ and $75.6 \%$ respectively.

\section{Breeder's weight}

The effect of breeders' weight on fertility and hatchability is presented in Table 2. Weight of breeder did not significantly affect fertility and hatchability of total eggs set but significantly $(\mathrm{P}<0.05)$ affected hatchability of fertile eggs. Breeders weighing 181-200 $\mathrm{g}$ had the highest hatchability (79.22\%) and $\leq 140 \mathrm{~g}$ the least
(60.83\%). In contrast, breeders $\leq 140 \mathrm{~g}$ had the highest late embryo mortality $(20 \%)$ which differed significantly $(\mathrm{P}<0.05)$ from breeders in the weight group $141-160 \mathrm{~g}$ that had the least (9.67\%). However, this group did not differ significantly from breeders in the weight group; 161-180 (10.49\%), 181-200 $\mathrm{g}$ $(11.69 \%)$ and $>200 \mathrm{~g}(12.82 \%)$.

Ipek et al. (2004a) reported significant $(\mathrm{P}<0.05)$ effect of live weight of breeder on hatchability of fertile eggs set which is in line with the result of this study. The quails in their study were grouped into light (171200g), medium (201-230) and heavy $(>230 \mathrm{~g})$. Fertility for the groups were $87.7 \%, 90.0 \%$ and $93.6 \%$ respectively and corresponding values for hatchability were 
$76.5 \%, 82.9 \%$ and $85.2 \%$ respectively. Marks (1991) also made a similar observation which was corroborated by Narahari et al. (1988) who postulated that fertile eggs from moderately heavier dams hatched better than those from lighter dams. The non significant effect of breeder hen weight on fertility of Japanese quail eggs observed in this study had also been reported by Coban et al. (2008). They however observed that male breeder weight also affected egg fertility.

\section{Color}

The effect of color on fertility and hatchability is presented in Table 2. The color of quail had significant effect on fertility and hatchability of total eggs $(\mathrm{P}<0.001)$, hatchability of fertile eggs $(\mathrm{P}<0.01)$ and early and late embryo mortality $(\mathrm{P}<0.05)$ but did not significantly affect mid mortality and egg weight. Light brown quails had lower hatchability of total and fertile eggs $(23.71 \%$ and $35.71 \%)$ as compared to wild type or normal colored ones $(52.04 \%$ and $69.84 \%)$. Light brown, however, had higher $(\mathrm{P}<0.05)$ early and late embryo mortalities (21.43\% and $35.71 \%)$ than wild type (10.0\% and $11.77 \%)$. Color however, did not significantly affect mid embryo mortalities.

El-Fiky et al. (2000) estimated the fertility percentages for two color types of quail (Brown and White) to be $84.3 \%$ and $80.9 \%$. They also reported hatchabilities of $62.7 \%$ and $57 \%$. Similarly, estimates for embryo mortality were reported by the authors as $5.07 \%$ and $5.18 \%$ for early and $16.50 \%$ and $18.25 \%$ for late for the two color types respectively.

\section{Conclusion}

It can be concluded from this study that season, production system, flock age, mating ratio, color and breeder weight affects the fertility and hatchability of Japanese quail eggs. Thus, these factors have to be considered when raising breeder stock and collecting eggs for hatching.

\section{References}

Alaku, S.O. 1982. The influence of season on birth weight, body weight at 3 and 12 months in wadara calves in the Sahelian region of North eastern Nigeria. World Review of Animal Production. 18:23-32.

Altan, Ö and Oğuz, I. 1993. Effect of mating ratios and parental age on fertility, hatchability, duration and recovery of fertility in Japanese quail (Coturnix coturnix japonica). Ege University Ziraat Fakültesi Dergisi 30(1-2), 57-64.

Coban, O., Lacin, E and Sabuncuoglu, N. 2008. Effect of some parental and environmental factors on some reproductive traits of Japanese quails. Italian Journal Animal Science 7: 479-486.

Coony, W. T. 1943. Pre-incubation humidity variation effects on chicken eggs hatchability. Oreg. Agricultural Experimental Statistical Technology Bulletin, Wiley and sons, Inc., New York.

Dere, S, Inal, S. Caglayan, T. Garip, M. and Tilki, M. 2009. The effects of parent age, egg weight, storage length and temperature on fertility and hatchability of Japanese quail eggs. Journal of Animal and Veterinary Advances 8(7):1289-1291.

El-Fiky, F. A., Aboul-Hassan, M. A., Attalah, G. E. Y. and Batta, S. S. 2000. Comparative study of reproductive traits in two strains of Japanese quail. Fayoum Journal of Agricultural Research and 
Development 14:206-212.

Encarta 2007. Microsoft Students Encarta Dictionary. Microsoft Corporation Inc.USA.

Erensayin, C. 2002. Influence of parental age on fertility, embryonic mortality and hatchability in Japanese quail. Journal of Central Animal Research Institute 2(1):47-50

Fasenko, G. M., Robinson, F. E and Hardin, R. T. 1992. Variability in preincubation embryonic development in domestic fowl. 2. Effects of duration of egg storage period. Poultry Science 71:2129- 2132.

Gebreil, O.S.R.A 2002. Effect of age, sex ratio, and male replacement on reproductive performance of quail. M.Sc. thesis, Department of Animal production, Faculty of Agriculture, Cairo University.135pp.

Inosco Jr, W.M., Maclaury, D.W., Begin, J.J. and Johnson, T.H. 1971. The relationship of egg weight to hatchability of coturnix eggs. Poultry Science 50, 297-298.

Ipek, A., Sahan, U. and Yilmaz, B. 2004. The effect of live weight, male to female ratio and breeder age on reproduction performance in Japanese quails. (Cortunix cortunix japonica). South African Journal of Animal Science 34(2):130-134.

Islam, M.S., Howlinder, M.A.R., Kabir, F and Alam, J. 2002. Comparative assessment of fertility and hatchability Barred Plymouth Rock, White Leghorn, Rhode Island Red and White Rock Hen. International Journal of Poultry Science 1: 85-90.

Jadhav, N.V. and Siddiqui, M.F. 2007. Handbook of poultry production and management. $2^{\text {nd }}$ ed. Jaypee Brothers Medical publishers Ltd. New Delhi,
India. 383pp.

Lowe, P.C and Garwood, V.A 1977. Chick embryo development rate in response to light stimulus. Poultry Science 56: 218-222

Mandour M.A. and Sharaf, M.M. 1993. Influence of age, mating ratio and crossing on hatching performance of Japanese quail eggs. Egyptian Journal of Poultry Science 13:393409

Mani, A.U., Garndawa1, I.I and Usman, B.A. 2008. Effects of pre-Incubation storage on the hatchability of quail (Coturnix coturnix japonica) eggs in the Sahel Region of Nigeria. International Journal of Poultry Science 7(4):350-354.

Marks, H. L. 1991. Divergent selection for growth in Japanese quail under split and complete nutritional environment. 4- Genetic and correlated responses from generations 12 to 20. Poultry Science 70:453-462.

Narahari, D., Aboul-Mujeer, K., Thangavel, A., Ramamurthy, N., Viswanathan, S., Mohan,B., Mur u gan a nd a n, B. and Sundararasu, V. 1988. Traits influencing the hatching performance of Japanese quail eggs. British Poultry Science 29:101-112.

NRC 1994. National Research Council, Nutrient Requirements of Poultry. 9th Ed. National Academy of Sciences, Washington, D.C. USA.

Reddish, J. M., Nestor, K. E., and Lilburn, M. S. 2003. Effect of selection for growth on onset of sexual maturity in random bred and growth of selected lines of Japanese quail. Poultry Science 82: 187-191.

Reynnells, R.D., Schuknecht, T., Grala, B.F and Coleman, T.H. 1977. Effect 
of preincubation holding condition on hatchability of Bobwhite and coturnix quail eggs. Poultry Science 56: 1750-1751.

Rizk, R., Zeweil, K., El-Zawat, $M$ and Abou Hafsa, S. 2006. Effect of flock age and dietary fat on production and reproduction performance in Japanese quail. In: CD-Rom Abstracts and Proceedings of XII European Poultry Conference, September, 10-14, 2006, Verona, Italy, N 10190.

Roshdy, M., Khalil, H. A., Hanafy, A. M and Mady, M. E. 2010. Productive and reproductive traits of Japanese quail as affected by two housing system. Egyptian Journal of Poultry Science 30 (I):55-67.

Sahan, U. and Ipek, A. 2000. Effects of breeder age and incubation humidity on hatching characteristics of broiler breeder eggs. Journal of Poultry Research 2:11-14.

Sari, M., Tilki, M., Saatci, M., Isik, S and Onk, K. 2010. Effect of parental age, egg weight and shape index on hatchability traits and liveability in Japanese quail (Coturnix coturnix japonica). Fyrat Universitesi Saglik Bilimleri Veteriner Dergisi 24(2):9397.

Sayed, S.M.A. 2006. Studies on some factors affecting productive performance and fertility of Japanese quail (Coturnix coturnix japonica).
M. Sc. Thesis Faculty of Agriculture, Al-Azhar University, Cairo, Egypt.83pp.

Seker, I, Kul, S and Bayrakter M. 2004. Effect of parental age and hatching egg weight of Japanese quails on hatchability and chick weight. International Journal of Poultry Science. 3(4):259-265.

Sexton, T.J. 1977. Relationship between number of sperm inseminated and fertility of turkey hens at various stages of production. Poultry Science 56:1054-1056.

Tona K., Bamelis F., Coucke W., Bruggeman $V$ and Decuypere $E$. 2001. Relationship between broiler breeder's age and egg weight loss and embryonic mortality during incubation in large-scale conditions. Journal of Applied Poultry Research 10:221-227.

Uddin, M.S., Paul, D.C. and Haque, Q.M.E. 1994. Effect of egg weight and pre-incubation holding periods on hatchability of Japanese quail eggs in different seasons. AsianAustralasian Journal of Animal Science 7(4):499-503.

Woodard, A.E., Abplanalp, H., Wilson, W.O. and P. Vohra, P. 1973. Japanese quail husbandry in the laboratory. Department of Avian Sciences, University of California, Davis, CA, 95616.

Received: $15^{\text {th }}$ September, 2014 Accepted:22 ${ }^{\text {thd }}$ February, 2015 